\title{
Analysing Complex Political Change by Applying the Concept of Regime Change: Identifying the Transformations within the Japanese Political-bureaucratic-business Regime
}

\author{
Christian Ploberger ${ }^{1}$ \\ ${ }^{1}$ Department of Political Science and International Studies, University of Birmingham, Birmingham, Great \\ Britain \\ Correspondence: Christian Ploberger, Department of Political Science and International Studies, University of \\ Birmingham, 55 Kings Road, Erdington, Birmingham, B 23 7JN, Great Britain. Tel: 44-78-1036-3780 E-mail: \\ cploberger@hotmail.com
}

Received: August 16, 2012 Accepted: September 8, 2012 Online Published: November 30, 2012

doi:10.5539/ass.v8n15p12

URL: http://dx.doi.org/10.5539/ass.v8n15p12

\begin{abstract}
The paper highlights the relevance of the concept of regime change for addressing the challenges involved in analysing political developments and complex, incremental, change. The overall focus is on the occurrence and dynamic of complex political change: Why it happens; what are the drivers and how we identify the impact of domestic and international factors in that process. To demonstrate its application the concept of regime change is applied to the case study of Japan. It is argued that the concept of regime change will enable us to bridge the gap between the political science approach, with its emphasis on identifying law-like regulations, and the area studies approach with its focus on the particularities of specific cases.
\end{abstract}

Keywords: complex political change, regime, state theory, structure and agency, Japanese politics

\section{Introduction}

When considering the variety of political systems, the trajectory of national developments and the diversity of state-market relations the complexity of political change we can observe in the process of state formation and state development becomes evident, as does the challenges of identifying an approach which could be used to analyse complex and incremental change within this range of cases. The argument presented in this paper is that the concept of regime change will offer such an approach by providing a principal framework of analysis without ignoring the particularities of individual case studies. Recognising the challenges inherit in such an undertaking, the paper will highlight the feasibility of the concept of regime change in analysing complex political change within a wide range of case studies which are quite distinctive in their nature. However, a number of clarifications are required: the specific meaning of a regime; how we interpret change, as well as the task and legitimate terrain of political analysis. The paper will start with outlining the concept of regime change, before applying the theoretical approach to a concrete case study, that is, in analysing complex political change in Japan.

\section{Outlining the Concept of Regime-change}

Applying the concept of 'regime change' requires a number of specifications. The concept of regime as applied in this paper differs from that commonly used, as it refers neither to a government nor to the state. Instead, a regime refers to the middle level of cohesion in the political economy of a state, to the shape, consistency, and predictability of its political economy (Pempel, 1998, 20). Fishman argues that a regime should be considered as the formal or informal organisation at the centre of political power, determining who has access to political power. The distinctiveness of a 'regime' is illustrated by its characteristic as it is a more permanent form of political organisation than a specific government, but typically less permanent than the state $(1990,428)$.

In outlining the key elements of a regime, Pempel identifies: socio-economic alliances, political-economic institutions, and a public policy profile. However, he continues to argue that tangible interests, embedded in economics and material welfare are of equal importance (Pempel, 1998, 20-21). It is therefore crucial to appreciate that a regime does not just emerge, indeed, the occurrence and continuation of a 'regime' relates to specific ends: the use of political power for the benefit of the participants involved. 
This paper advocates the notion that a regime represents a particular structural entity as it provides the framework, for political, economic and social actors, comparable to the state, which provides the structural environment for a regime. Figure 1 offers a schematic of a regime, and its relations to the state. Identifying a regime as a structural entity with crucial consequences for other actors, raises not only fundamental questions of the state-regime interface but equally of the nature of the state itself.

\section{State, Regime and Government}

$$
\begin{aligned}
& \mathrm{PA}=\text { Political Actor } \\
& \mathrm{EA}=\text { Economic Actor } \\
& \mathrm{SA}=\text { Social Actor } \\
& \text { Gov }=\text { Governemnt }
\end{aligned}
$$

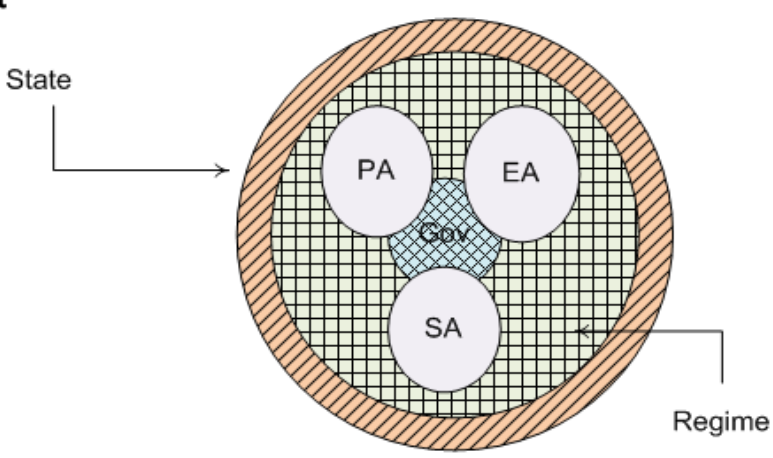

Figure 1. Identifying a regime

\section{The State as a Structural Variable}

By emphasising that the state provides the framework for a regime, it is therefore essential to develop a firm By emphasising that the state provides the framework for a regime, it is therefore essential to develop a firm understanding of the nature of the state. After all, how we interpret the nature of the state - either as a static unit or as a social construction - will have a critical impact on how we perceive the dynamic of political change.

Poulantzas argues that the state is the material condensation of relationships, based on the outcome of power struggles within the state (1978, 142-144). Jessop speaks of 'state projects,' highlighting the state as both a site and object of strategic elaboration, emphasising that we should interpret the state as a manifestation of the power of social forces, acting in and through it (1990, 9-10). Hence, we should no longer consider the state as a neutral institution. Take the example of a socialist state, a free-market approach to economic activities would hardly be a political option. Since a particular state will favour a particular set of policy strategies, the nature of a particular state has profound implications for political change by not only limiting the options available for organising and determining the state-economic and state-society relationship, but equally by affecting regime formation and regime change. The varieties of state-society and state-market relations, indeed the diversity of modern capitalist and non-capitalist states we can observe reminds us that decisions regarding state and economic developments are made within a particular national context and thus lead to particular national trajectories of development. North $(1999,12)$ also highlights the relevance of the existing state structure, as political, economic, and social actors behave strategically and tactically orientate themselves in the context and logic of the existing state structure, classifying them as an institutional matrix.

Even as the state provides a contextual framework for other actors, it is crucial to be aware, as emphasised by Cerny, that the state should not be interpreted in a static way, as one can identify ongoing processes within the state structure, that is, processes of interrelated dynamics between the political and the socio-economic environment; what Cerny refers to as structuration (1990). This crucial relevance of state structure in contextualising political behaviour can also be observed through the partial re-creation of state institutions along the existing state structures, identifiable in a path dependent trajectory of political change, especially in the absence of a revolutionary process. Consequently, the position advocated in this paper is that a state does not just exist but is an incarnation of social, political and economic relations, with the implication that the state as a structural variable is open to change.

It is worth noting that the relevance of the state endures despite claims that globalisation has rendered the state obsolete, highlighted by frequent assessments such as the occurrence of a 'borderless' economy' or the 'end of territory'. Signalling the dawn of a 'global area' where the state is replaced by a process of globalisation based on the market. Indeed, we have experienced a revolution in communications and transport technologies which led to a significant re-defining of distance and territorial space along with the expansion of global production networks, global financial networks, global sourcing and 'country hopping' that are all indications for redefining 
space in a more globalised world. Still it is an open question as to what extent such developments render the state obsolete? After all, curtailing states capacities does not equate to considering the state to be redundant. Scholte maintains that although the challenge of economic globalisation manifests itself through a transformation of geography, yet globalisation did not eliminate the territorial sphere, instead it reconfigures geography and thereby repositioned the relevance of the state (Scholte, 2005).

Besides, not only do corporations still have to operate within particular national, regional and international regulatory systems, but markets too depend upon the regulatory power of states to function properly. Thus it would be safe to argue that globalisation, in the words of Cerny, has altered the scale of the 'structural field of action', as it changed the relationship between the provision of different kinds of goods and assets thereby reducing the state's capabilities to influence economic development $(1994,328)$. The state continues to provide a significant space for a distinct national process of adaptation and development. The process of regime formation and regime change are clear indicators of the ongoing relevance of national space.

By acknowledging the role of the state as a fundamental structural entity, the state also provides the framework for a specific regime; consequently, a specific state and a particular regime are intimately related to each other. This has critical implications for regime development and regime change, by limiting the options available.

\section{Identifying the Probability for Regime Change}

When addressing the topic of regime change, identifying the existence of a regime represents the first step. As the concept of a regime, as advocated in this paper, is neutral to both 'strong state' and 'weak state' interpretations and with regards to democratic and non-democratic states alike, we will be able to identify the existence of a regime, although differing in scope and nature, among a wide variety of cases studies. While the concept of regime change can be applied to both democratic and non-democratic states, there are implications regarding the analytical separation of government, regime and the state, within a non-democratic setting. The analytical separation between a government, a regime and the state, as applied hitherto within a democratic setting, is less applicable in the case of a non-democratic rule.

Take for example the case of a one party-state rule in which all political power is centred on and legitimised by the political party in power. The existence of a political space between a government, a regime and the state, which can be identified within democratic states, is of lesser significance or may almost be non-existent within a non-democratic setting. This has important consequences for the occurrence of regime change, as the pressure for changes could raise critical questions about the continuous dominance of a particular party and the very nature of the state. This in turn could generate a more resistive behaviour towards the occurrence and dynamic of change, which could lead to an accumulation of pressure and lead to a rather eruptive process of adaption at a later stage.

A further step is to identify the underlining causes of the occurrence and dynamic informing the transformation process. The term 'change' does not indicate the extent of the transformation. Instead, the term 'change' encompasses a continuum from partial adjustments to a fundamental breakdown. Yet, without pressure of some kind, we would not witness the occurrence of change at all. Though the origins of pressure for change can differ in its origins: it may be based on a comparison with other the developments of other states; generated by inherent internal processes of a regime, or based on domestic changes as for example social, economic, or political developments or on a combination of several of these developments.

A critical linkage with regard to how we identify the occurrence and dynamic of change exists with how we interpret crisis. A crisis, as emphasized by Hay, does not merely represent a moment of impending breakdown, but rather a strategic moment of transition, a decisive moment in the transformation of the state, where an actual political structure undergoes fundamental change $(1999,320)$. Ikenberry also describes 'crisis' as a critical turning point, providing the opportunity of re-shaping existing institutions (1995, 59-60). Thus, even as crisis represents a critical point in the evolution of both a regime and the state, it does not signify an immediate breakdown, but rather an opportunity for adaptation by stimulating change.

Essential to the understating of the process and dynamic of change is the distinction between change within or of a regime. As emphasized by Sztompka change can take different forms: 'change in composition, change in structure, change of function, change of boundaries, and change in the relations of the subsystems and change in the environment' $(1993,5)$. Offe distinguishes between structural and conjunctural modes of political rationalities, whereas the conjunctural mode refers to a response in which a solution is sought to be found within the pre-existing and largely unmodified structures of the existing institutional compromise, the structural mode points towards a fundamental transformation - a restructuring - of the existing institutional compromise (1985, 223-226). 
Figure 2 to 4 represent illustrations of the difference stages of regime change. Starting with a stable regime (Figure 2), Figure 3 indicates the nature of change within a regime by depicting one of its major constituting parts (for example EA) weakened and in doing so impacting on the regime as well. To provide an example for this type of change we cite the economic sector which represents a cohesive group at an earlier stage, but over time becomes less coherent as divergent interests within this group emerge (e.g. between business and industry or between small and big business) and become more solidified. Hence, this stage indicates the occurrence of change within the regime. Figure 4 indicates not only that a further pillar (SA) of the regime are weakened, but in addition, that the regime itself loses its coherence, consequently that denotes a change of the regime instead of a change within the regime. The process is comparable to that indicated in Figure 3, but now more parts of the regime are confronted by an increasing internal weaknesses, undermining their ability to represent themselves as a coherent group, thereby rendering the regime's ability to provide a coherent structural entity obsolete.

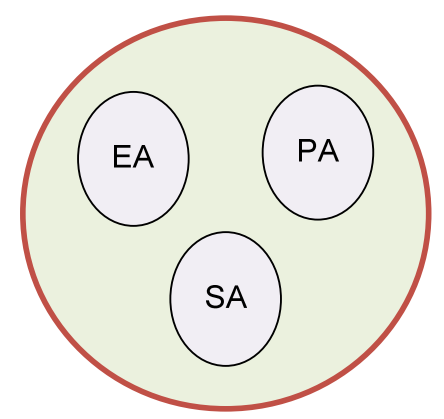

Figure 2. Stable regime, $\mathrm{PA}=$ political actor $/ \mathrm{EA}=$ economic actor $/ \mathrm{SA}=$ social actor

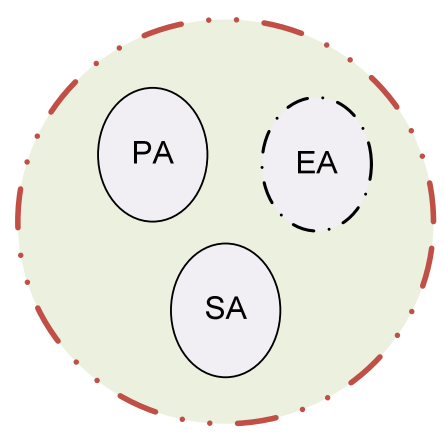

Figure 3. Change within the regime

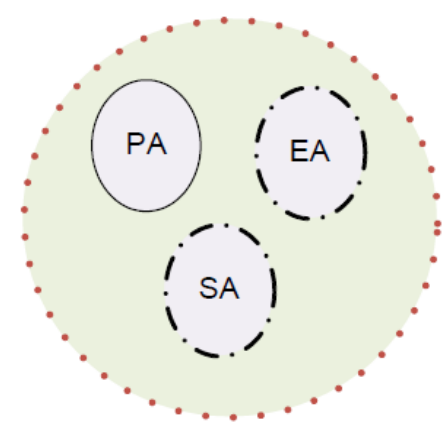

Figure 4. Change of the regime

\section{Analysing the Dynamic and Extent of Change of the Japanese Political-bureaucratic-business Regime}

The Japanese regime represents a good example of the problem of analysing complex political change. The timeframe selected encompasses the period from the late-1960s to the late 1990s. By applying a longer timeframe, it will enable us to cover both the success and failure of the Japanese regime. In doing so, the paper will avoid a common one-sided focus, characterised by evaluating either the success or the failure of the political-bureaucratic-business regime. The critical question raised from the perspective of regime change is whether the 1990s signify a fundamental challenge in which the regime's internal coherence was undermined or does this period merely represent a cyclical recurrence of economic crisis? 


\subsection{Identifying the Japanese Political-bureaucratic-business Regime}

The Japanese regime consists of the Liberal Democratic Party (LDP), the bureaucracy, and the business community. They were bound together by their particular interests. LDP-business relations formed a keystone of the regime, which was based on shared interests as business valued a stable government that was tolerant of business interests as well as favouring economic growth and macroeconomic stability. As emphasised by Richardson, business and their large business federations were the most important source of financial funding to the LDP, though from the 1980s onwards banks and other financial institutions accounted for nearly 50 percent of all business donations $(1997,177,180)$. Ikuta highlights, that business could contribute in other ways to the LDP's electoral success, citing the example of the construction industry, which not only provided financial contributions but equally reliable support during elections in mobilising its five million workforce to vote for the LDP $(1995,105)$. A national consensus of 'catching up with the West', which existed since the Meiji reforms (1868), was characterized by a public acceptance to facilitate economic development and a drive for modernisation. This was also critical in facilitating a cooperative relationship between politics and business in providing a source for acceptance of the regime's objectives within the wider population.

Even as the relationship between the LDP and business represented an important pillar of the regime, the role of the bureaucracy within the regime should not be underestimated as the bureaucracy wielded a wider influence within the Japanese state and society, as Japan's bureaucracy was not only highly respected, but also seen as very competent. Another factor in underlining the significance of the bureaucracy is that, in the words of Nakasone, 'the Japanese bureaucracy, through its cumulative knowledge and experience, works like a giant think tank for the nation.' $(1998,41)$ When addressing the bureaucratic-business nexus, we can identify a combination of statutory powers including control and regulation activities (for example project approval, licensing, credit granting) on non-statutory influence, characterised by administrative guidance (where a ministry gives advice, makes suggestions, and provides instructions etc). Shino points out that even as administrative guidance refers to administrative actions without a legal binding force, it was frequently practised and achieved considerable results $(1984,204)$. Schwarz stresses that the willingness of the business community to accept administrative guidance derived from long-standing business-government relationships, adding, that it was rarely imposed on a recalcitrant private sector $(1998,27)$. After all, Sugimoto argues, bureaucratic instructions often reflected a previously reached agreement with business representatives $(1997,197)$.

The bureaucrat's dependence on the business community for specific industry related information also enabled the business community to wield direct influence on the activities of the bureaucracy. Amakudari, the practice of employing retired bureaucrats within the business sector added to the influence business had on the bureaucracy. Usually, these ex-bureaucrats were re-employed in companies, which have close working relations with the ministry they worked for before their retirement. It should be noted, as pointed out by Ikuta, that the re-employment of former bureaucrats also offered some advantages to the company they were employed with as the former bureaucrats not only had an insight into the understanding of how their agencies worked, but also valuable links with politicians $(1995,16)$. Thus, as argued by Wilds and Wright, with a reference to Samuel, 'the bureaucracy does not dominate; it does not lead, it negotiates, hence the relationship between the bureaucrats and the firms is based upon what is described as 'reciprocal consent', yet the authors insist that this should not be interpreted as consensus $(1991,44)$.

Addressing the bureaucratic-politics nexus, we can identify a variety of different views as to how this relationship is structured. One view identifies politicians as the decision makers whereas bureaucrats merely implement their policies. Another view suggests that both bureaucrats and politicians contribute to the policymaking process. Yet another view highlights the dominance of bureaucratic influence, which is based on the information they hold in particular areas and the role they play in the preparation of bills. The legislative process obviously restrains the bureaucratic influence, as bureaucrats have to rely on politicians to propose and pass bills on their behalf. Nevertheless, as indicated by Sugimoto, the influence of the bureaucracy on the legislative process is noticeable, because it is the bureaucracy, which 'draft, formulate, and finalize an overwhelming majority of bills' (1997, 200). Hence, as long as politicians rely on drafts prepared by bureaucrats, the bureaucrats will wield an influence in the legislative process. Schwartz also reminds us, that a lack of meaningful Diet involvement in policymaking did not lead to a lack of participation by the ruling-party, as ministry officials to consult with the LDP at every stage of policymaking $(1998,23)$. The long tenure of single party governance certainly facilitated the bureaucratic-politician relationship, as a repeated shift in political power would, as argued by Craig, require a mechanism within the bureaucracy to handle shifts of policy strategies $(1975,18)$. Nor was there a requirement for the LDP to penetrate the bureaucracy too deeply or to purge bureaucrats, who agreed too strongly with a rival party (Michio \& Kraus 1984, 141). 
This brings us to another significant feature of the Japanese regime, the long dominance of Japan's politics by a single party, which is a central feature of the Japanese regime. The Liberal Democratic Party's (LDP) hold on power between 1955 and 1993, commonly described as the '1955 system', represents a dominant feature of Japan's post-war party politics with significant implications for the Japanese regime. Though the merger of the Liberals and Democrats was neither straightforward, nor seen as anything more than just another fragile, short-lived, alliance of the ongoing partisan alignments in early post-war Japan, yet the LDP became the cornerstone of political power in Japanese party politics. Despite that the LDP successfully managed to stay in power over a period of thirty-eight years, serious conflicts erupted within the LDP. Richardson argues that one can identify recurring characteristics of these crises beginning with a leader's loss of credibility; intensification of factional strife; anxiety among junior members of the party and rumors or proposals of a party split (1997, 76-77).

A crucial role in keeping the party united and for holding political power was played by the factions within the LDP. To win a majority in the House of Representatives the LDP had to run more than one candidate in each electoral district, but the party was unable to sponsor one candidate against another in a single constituency. Factions provided a way for the LDP to overcome this structural dilemma. However, the significance of factions does not end here as they provided vital financial support for individual, rank and file members and individual candidates to win party endorsement and to gain access for election campaign funding. Another important function of fractions is their role during party president elections, in which the leaders of each faction compete with one another to become the next party president. To win the LDP presidency during the period of 1955-1993 equated to be becoming the next prime minister of Japan. The frequent reshuffling of the cabinet and the short cabinet tenure highlights the significance of this internal party dynamic. As pointed out by Richardson, the time that each prime minister stayed in his job, was not so much a concern of the voters, as of the factions because they decided when a president had to step down $(1997,67)$. Hence, factionalism also introduced a continuous intraparty competition over influential positions.

Even as the specific links between these three pillars of the regime were mutually re-enforcing and proved to be quite enduring, this does not indicate the absence of conflict within the regime. Figure 5 provides an illustration of the Japanese regime and its internal relationships, moreover it indicates that the state provides the structural framework for a regime, and consequently for regime formation. Consequently, developing a comprehensive understanding of the nature of the Japanese state represents an essential task of the political analyst.

\subsection{The Nature of the Japanese State}

Describing the Japanese state as a developmental state is one of the most common descriptions we can identify within the literature. Johnson describes the Japanese state as 'plan-rational' and highlights the role the Japanese state played during the industrialization process. This places the Japanese state in opposition to a purely 'market-rational' model (1995, 8-10). Alike, Wilks and Wright also describe the specific features of the developmental state as plan-rational, with an explicit focus on industrial policy to sustain 'high-speed' economic growth and a general consensus on growth as part of an overarching set of goals for society, as well as the existence of a powerful bureaucracy $(1991,37)$. Even as these descriptions unveil central aspects of the nature of the Japanese state, further qualifications are required. Hall highlights that the Japanese state challenges the conventional way we think about economic management, going beyond common dichotomies of 'politics' and 'market'; 'public sector' and private sector. Instead, the Japanese state to some extent provides us with a specific example of a joint management involving the 'public' and 'private' spheres of economic activities, suggesting the possibility of a state intervention system, which not only supplements the market but eventually enhances market discipline (1995, 484-491). Gao emphasizes that the Japanese state focused less on the improvement of individual economic well-being, than on enhancing national power, thereby replacing the economic man with the political man, adding that Japan's developmentalism represents a particular example of the inseparability of industrialization and nationalism $(1997,38,48)$.

Even as the state provides the structural framework for the existence of a regime this does not deny the impact of interests that the various parts of a regime represent. In addition, the failure and success of a regime in implementing its goals also represent crucial issues for the stability and acceptance of a regime as well as for the occurrence of pressure for change. 


\section{Japanese Regime}

Japanese Regime and ist internal links
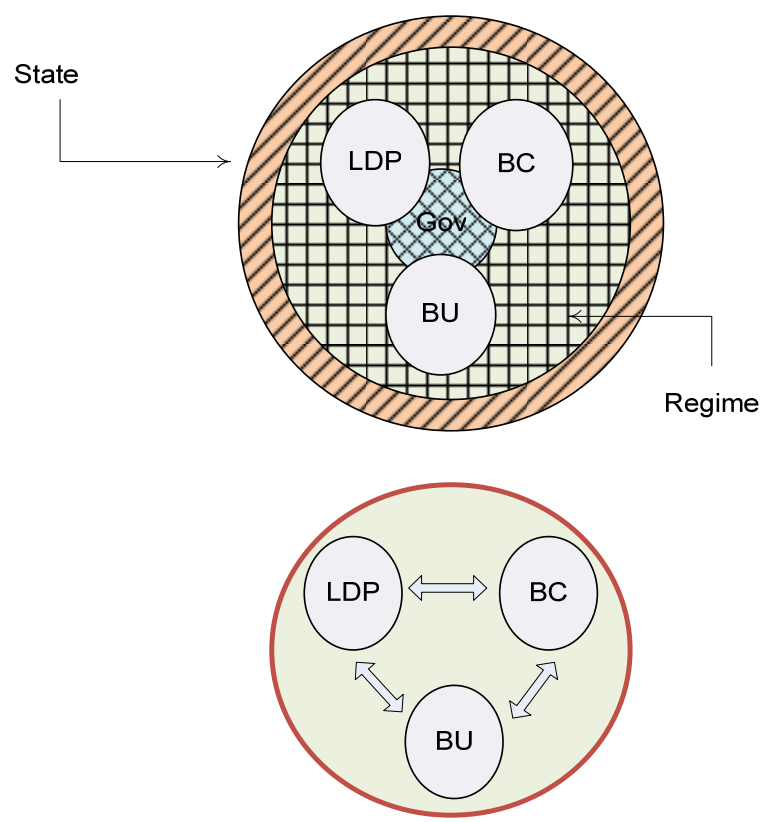

LDP $=$ Liberal Democratic Party $/ \mathrm{BC}=$ Business Community $/ \mathrm{BU}=$ Bureaucracy

Figure 5. The Japanese regime

\subsection{Success and Challenge}

Japan's economic miracle occurred between the mid 1950s and the early 1970s and was followed by the phenomenon of Japanese super-industrialism in the mid-1980s. The astonishing success Japan enjoyed until the early 1990s reflected a wider consensus at that time, in that the Japanese economy had 'out-performed' other industrial nations, no matter which economic indicators are used - growth output, growth of employment, growth of $\mathrm{R} \& \mathrm{D}$, inflation rate or unemployment figures.

Yet, this economic success was neither anticipated nor a likely outcome, as the country was not only devastated by the Second World War, but also lacked natural resources. However, Japan did posses extensive human capital as well as knowledge in manufacturing and production technology (Kingston, 2001, 36) that facilitated its recovery and ensuing economic success. There were also external factors, such as the unhindered access to the US market and the economic stimulus provided by the Korean War, which helped in overcoming the post-war recession. A fixed and low exchange rate of the Yen to the US dollar (Y360-1\$) also favoured the export of Japanese products. An additional and significant factor for the success of Japan's early economic recovery relates to the emphasis the Japanese regime placed in the improvement of production technology. Gao highlights that as early as the 1950s production technology was identified as a subject for promoting national comparative advantages $(1997,29)$. Takuro observes that the period of mid-1950s until the early 1970s saw Japan succeed in creating the most competitive heavy industrial sector in the world $(1989,49-50)$.

When considering the role of the Japanese regime during this period a variety of aspects need to be taken into consideration. Among them, the scope and extent of economic planning and how the regime managed to implement its policies. To begin with, we have to recognise that there are inherent limitations to the scope of planning, and that the economic model was characterised by an original blend of planning instruments and market mechanisms. It is imperative to recognise, as Huber notes, that the focus of the economic planning concentrates on what is called the 'strategic economy', adding that the government's method of intervention was characterised by setting ends, rather than to dictate means (1994, 14-15). Allen adds, that the nature of the economic planning is best described as 'indicative' $(1981,3)$. Alike, Komiya notes that Japan's national economic plan should be interpreted as a long-term forecast, rather than a rigid plan, which must be followed faithfully (c1990, 281). Indeed, the general economic plan provides a framework, whereas more specific goals were outlined in the so called medium-term 'elevation plans', which are formulated by MITI's industrial bureaus in close corporation with the concerned industries (Huber, 1994, 6). 
The formulation and implementation of these economic plans provides a good example for the regime's internal relationships as different sections of the bureaucracy like MITI, the Ministry of Finance (MoF) and the Bank of Japan (BoJ) played important roles in facilitating the implementation of the economic plan. Whereas MITI operated through neo-zaibatsu, industrial associations and the formation of cartels, the influence of MoF and $\mathrm{BoJ}$ were mainly based on their ability to provide different forms of capital to specific business sectors. However, the incentives provided for selected industries were linked to clearly defined ends. The deliberate restriction of competition represented another guiding principle as all-out competition was interpreted as destructive as it would scatter and waste capital. Still, as emphasized by McMillan, it was understood that market competition should be maintained and for the most part the Japanese regime restrained but did not reject market competition $(1996,97)$. Hence, the various companies actually competed with each other in implementing MITI's objectives (for example raising the quality or lowering the costs of products) and for the promotional measures (i.e. bank loans, tax incentives etc) offered by MoF. Another important advantage of Japan's development during this period was that Japan still was a late developing country. This in turn enabled it to take advantage of technical developments in other countries, by enhancing its international competitiveness without the need for expensive and risky R\&D investments.

However, despite the regime's success, its ability to address crisis situations was severely tested in the early 1970s. To begin with, the regime faced a number of domestic challenges, which were closely related to the very success of the rapid economic change and the growth paradigm of the regime. These domestic challenges centered on the low living conditions and industrial pollution the Japanese people had to endure. (Note 1) An additional challenge for the regime's economic strategy arose with the kutabare GNP movement (down with GNP), which surfaced in May 1970. This movement attacked a core consensus on which the regime rested. These episodes provide us with a good example of how success and development can lead to a challenge for a regime. However, the Japanese regime was able to address these concerns and consequently managed to retain its internal cohesion. Yet, another fundamental challenge for the Japanese regime originated within the international system, namely the First and Second Oil crises. In evaluating the impact of the first oil crisis (1973), Masu notes, that the Japanese economy experienced a harsh period of inflation, a drop in the growth rate, and a shift to a balance of payments deficit (1988, 91-92). Takuro highlights that the 1973 oil crisis led to a 'structural oil crisis recession' which lasted from 1974 to 1975 and that manufacturing production did not regain their former level for five years $(1989,49)$. The negative impact of the two oil crises, as pointed out by Masu, triggered an unprecedented change in the structure of the Japanese economy, leading to unequal development between the basic materials and assembly industries, after all, the basic material industries had been a heavy user of energy, and consequently were hardest hit by the rising energy costs $(1988,92)$.

Implementing structural adjustments within declining industries represented one of the most difficult problems the Japanese regime faced during that period, but an essential requirement in addressing the challenges it faced. However, it showed a remarkably willingness to carry out these adjustments. Allinson contends that, Japan acted resolutely in concentrating on cutbacks in many depressed industries, referring to the structural adjustment process in the shipbuilding industry as an example (1997, 131-136). However, the Japanese regime also responded with defensive measures, leading to a policy reversal when compared with the 'rapid-growth-era'. Kingston assesses the change of policy by pointing out that there was a shift from 'picking winners' to a policy favoring recession cartels with subsidies and tax breaks for 'sunset industries', consequently slowing down the restructuring process of the economy $(2001,44)$.

These crises and developments provide clear evidence for the impact and challenges international developments can represent for a regime and in potentially undermining a regime's earlier success. However, these episodes also validate the notion that the occurrence of a crisis does not indicate the immediate breakdown of a regime, instead, as emphasized before, a crisis represents a strategic opportunity for re-thinking policy strategies. After all, these structural adjustments, the shift from the heavy industrial sector to the assembly industry, were instrumental in Japan becoming a first rank industrial power in the mid-1980s. However, changing from a follower to a leading economic nation, Japan no longer could profit from its status as a late developing nation as it had done before. Nonetheless the Japanese regime did show a remarkable ability of adapting to critical challenges during this turbulent period of post-war development and it facilitated Japan's rise to an economic superpower.

\subsection{The Twilight of the Regime}

The beginning of the 1990s witnessed a fundamentally different development approach with regard to the Japanese regime, as development within it and in its relations with the wider public started to undermine its internal coherence. Though the burst of the 'economic bubble' signaled a critical change in post-War Japan, but 
despite the magnitude of its impact, this alone did not lead to the unraveling of the regime. Indeed, a number of other developments, in which some of them had developed over a long period and were linked to the very success of the regime, are equally critical when assessing the decline of the Japanese regimes' internal coherence.

Without question, the impact of the bursting of the economic bubble was dramatic, as noted by Kingston, in that the credibility of Japan's financial system suffered tremendously by the apparent paralysis of the bureaucracy and politicians to address the financial sector crisis during the 1990s $(2001,102)$. The problem of the non-performing loans reached significant proportions during the 1990s, and consequently threatened the very foundations of Japan's financial institutions to such an extent that a collapse of the entire Japanese financial structure was no longer perceived as impossible. The ensuring economic slowdown and the seeming in-activity or in-ability of the bureaucracy to engage with the challenge of this situation contributed to the erosion of public confidence in the bureaucracy. Especially, the reputation of the MoF suffered during the 1990s as it appeared to be either unable or unwilling to overcome the fundamental problems Japan's financial sector was confronted with. However, the reputation of the bureaucracy had already been tarnished from a decade long simmering scandal over HIV-contaminated blood used for blood transfusions. (Note 2) The slow and perceived un-coordinated reaction of the bureaucracy in the aftermath of the January 1995 Great Hanshin Earthquake (Kobe earthquake) further undermined the public confidence in the bureaucracy and stirred up public anger. (Note 3) Together, these developments further eroded the impressive reputation the bureaucratic had enjoyed within the Japanese society, which was already shattered by the Recruit Scandal (1988), the first major corruption scandal which involved members of the bureaucracy. Together, these developments lead to a change of public attitude towards the bureaucracy, which was no longer viewed as a civil service with high moral standards, characterized by extraordinary professionalism and a dedication to serve the whole nation. This change in attitude towards the bureaucracy also contributed to the unraveling of the Japanese regime as well.

The early 1990s witnessed another catalyst for change, as in 1993 the LDP was no longer able to contain its internal centrifugal dynamics and its biggest faction, the Takeshita, split. As a consequence, the LDP lost its ruling power after a period of 38 years. (Note 4) Kohno points out that there was a manifest public demand for reforming the existing electoral system as it represented for the public a major source of 'money politics' and the resulting corruption scandals (1997, 145-6). The continuous occurrence of financial scandals, in combination with the election vulnerability of younger Diet members and the unwillingness and inability of the LDP leadership in bringing about political reform represented a critical issue. In addition, the tremendous social change, which took place between the 1950s and the 1990s, led to wider changes within Japanese society such as the emergence of a mass society and increasing voter independence. Despite that the LDP, in the words of Purnendra, continued to 'attract a sizeable majority of urban voters and semi-urban middle class voters' consequently building up a reputation of a 'department-store type party, which had something attractive on offer to a wide range of customer' $(1997,17)$. Yet, the continuous eruption of corruptions scandals also tarnished the relationship between business and the LDP. Richardson highlights, that the Recruit scandal lead to an 'emergency' statement from the four major business organizations calling for a resolution of the LDP's leadership crisis and the development of a plan for party reform and business leaders began openly to discuss alternatives to the LDP rule $(1997,183)$. Thus, the pressure felt by younger Diet members set in motion, Kohno argues, a process were the perceived electoral vulnerability of younger LDP diet members informed their strategy to portray themselves as reformers and ultimately supporting the non-confidence bill of the opposition in the Diet, which brought down the LDP government (1997, 147-8).

What's more, the Takeshita fraction also went through an internal leadership struggle between Ozawa and Hata, which increased the sensitivity among the faction members to the public demands of reforms. Though there have been rare instances where LDP Diet members left the party (Note 5), however, in 1993, the LDP was no longer able to preserve its ruling power. Nevertheless, it is important to recall that the LDP remained the largest party in the Diet even after the 1993 elections.

Even as those developments already undermined the coherence of two pillars of the political-bureaucratic regime and consequently the regime's internal coherence, the third pillar of the regime, business, also experienced a critical challenge to its internal coherence. As a result of the economic success of the regime, parts of Japan's business community became increasingly competitive internationally and very successful in penetrating foreign markets. In doing so, they became more independent of the bureaucracy, especially from the financial incentives used by the Japanese regime for implementing its policy strategies, consequently reducing the leverage of the regime over this part of the business community. In addition, the international focused sector of the Japanese economy increasingly felt pressure from foreign governments for Japan to open its domestic market for foreign 
investment, which was vehemently resisted by the less competitive and productive domestic business sector. These discrepancies increasingly manifest themselves in the late $1980 \mathrm{~s}$, and began to undermine the coherence of the business sector and consequently its positions within the regime.

Together these developments not only undermined the acceptance of the Japanese regime within the wider public, but led to a development, which saw an unraveling of its internal structure. As the LDP lost its power and Japanese politics witnessed the re-emergence of shifting political coalitions, the former dominance of the LDP weakened. This had a crucial impact on its relations with the bureaucracy, since both sides now recognized that an alternative may exist to the LDP's former dominant position, consequently, their previous close relationship became more dissociated.

Equally, the developments within the business community not only increased the internal frictions within this pillar of the regime, but also undermined the links with both the LDP and the bureaucracy. It is also worth noting, that since Japan became a leading economic power the national consensus of 'catching up with the West' no longer bound the various actors together as it did before. This again provides a good example where success can undermine a regime, especially if it is not able to formulate a new 'general strategy' in addressing contemporary issues. One could assess that the Japanese regime, despite its success, very nearly outlived its relevance. Figure 6 presents an illustration of the process from a weakening to an unraveling of the regime's internal relationships.

\section{Change within the Regime}

The unraiviling of the regime

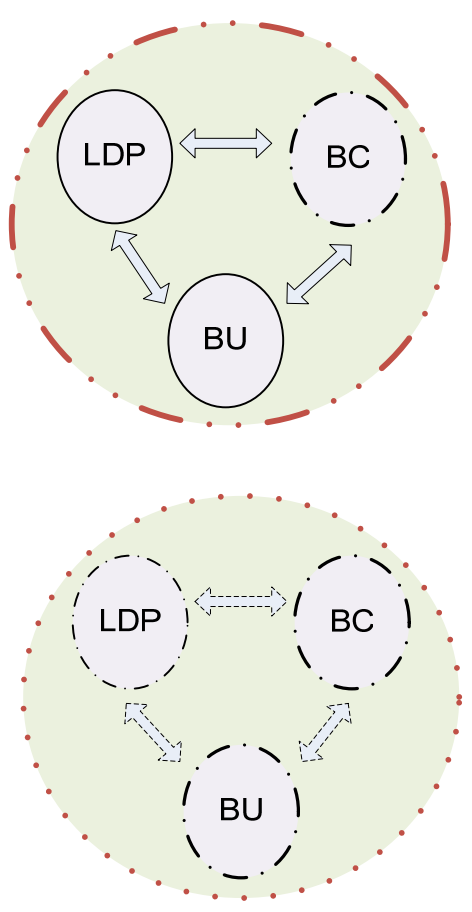

Figure 6. The Japanese regime - the process of change

Even so, despite that the regime's coherence is considerable as undermined and its former stable and mutually reinforcing internal relationships are in a state of decline, it would be premature to suggest that the 1990s witnessed the end the of the LDP-bureaucratic-business regime. However, it should be emphasized that the Japanese regime underwent a process of adaptation characterized by a change of the regime, instead of a change within the regime and we may witness the formation of a new regime in the near future

\section{Conclusion}

Applying the concept of regime change will offer a critical insight into the occurrence and dynamic of complex political change. Applying the concept of regime change also offers an approach which can transcend the nature of particular case studies and consequently be employed in a variety of different cases. Yet an extensive understanding of a particular case is required in order to identify the existing regime when applying the concept.

However, it is important to note, that applying the concept of regime change as a tool for analysing complex political change requires a more inclusive understanding of politics. Hence, the argument presented is that an overly narrow focus on government institutions would omit an analysis of the very substance of politics. After all, politics is made in the context of constraints and a particular environment. Consequently, analyzing complex political change requires an interdisciplinary approach 


\section{References}

Allen, G. C. (1981). The Japanese Economy. London: Weidenfeld \& Nicolson.

Allinson, G. D. (1997). Japan's Postwar History. Ithaca: Cornell University Press.

Cerny, P. (1990). The changing architecture of politics: structure, agency, and the future of the state. Lon-don: Sage.

Cerny, P. (1994). The dynamics of financial globalisation: Technology, market structure, and policy response. Policy Science, 27(4), 319-342. http://dx.doi.org/10.1007/BF01000063

Craig, A. M. (1975). Functional and Dysfunctional Aspects of Government Bureaucracy. In Ezra F. Vogel (Ed.), Modern Japanese Organisations and Decision-Making (pp. 4-33). Los Angeles: University of California Press.

Fishman, R. M. (1990). Re-thinking State and Regime: Southern Europe's Transition to Democracy. World Politics, 42(3), 422-440. http://dx.doi.org/10.2307/2010418

Gao, B. (1997). Economic ideology and Japanese industrial policy: developmentalism from 1931 to 1965. New York: Cambridge University Press. http://dx.doi.org/10.1017/CBO9780511665318

Hall, Peter A. (1995). The Japanese Civil Service and Economic Development in comparative Perspective. In Hyung-Ki Kim, Michio Muramatsu, T. J. Pempel, \& Kozo Yamamura (Eds.), The Japanese civil Service and Economic Development (pp. 484-505). Oxford: Clarendon Press.

Hay, C. (1999). Crisis and the structural transformation of the state: interrogating the process of change. British Journal of Politics and International Relations, 1(3), 317-344. http://dx.doi.org/10.1111/1467-856X.00018

Hiroshi, S. (1984). Administrative Guidance. In Ki-yoaki Tsuji (Ed.), Public Administration in Japan (pp. 203-216).Tokyo: University of Tokyo Press.

Huber, T. M. (1994). Strategic Economy in Japan. Boulder: Westview Press.

Ikenberry, G. J. (1995). Creating Yesterday's New World Order: Keynesian 'New Thinking' and the Anglo American Post War Settlement. In Judith Goldstein, \& Robert O. Keohane (Eds.), Ideas and Foreign Policy: beliefs, institutions, and political change (pp. 57-86). New York, Cornell University Press.

Ikuta, T. (1995). Kanryo: Japan's hidden government. Tokyo: NHK Publishing.

Jessop, B. (1990). State Theory: putting the capitalist state in its place. Cambridge: Polity Press.

Johnson, C. (1995). Japan, who governs? London: Norton.

Kingston, J. (2001). Japan in transformation, 1952-2000. Harlow: Pearson Education.

Kohno, M. (1997). Japan's Postwar Party Politics. Princeton: Princeton University Press.

Komiya, R. (1990). The Japanese Economy: Trade, Industry, and Government. Tokyo: University Press.

Masu, U. (1988). The Oil Crisis and After. In Ryutaro Komiya, Masahiro Okuno, \& Kotaro Suzumura (Eds.), Industrial Policy of Japan (pp. 89-117). San Diego: Academic Press.

McMillan, C. J. (1996). The Japanese industrial system. Berlin, New York: deGruyeter. http://dx.doi.org/10.1515/9783110812879

Muramatsu, M., \& Kraus, E. S. (1984). Bureaucrats and Politicians in Policymaking: The Case of Japan', Signs. The American Science Review, 78(1), 141. http://dx.doi.org/10.2307/1961253

North, D. C. (1999). Understanding the Process of Economic Change. Princeton University Press.

Offe, C. (1985). Disorganised Capitalism. Cambridge: Cambridge University Press.

Pempel, T. J. (1998). Regime shift: comparative dynamic of the Japanese political economy. London: Cornell University Press.

Poulantzas, N. (1978). State, Power, Socialism. London: New Left Books.

Purnendra, J. C. (1997). Party politics at the crossroads. In I. Jain Purnendra (Ed.), Japanese politics today (pp. 11-29). Melbourne: MacMillian.

Richardson, B. M. (1997). Japanese democracy: power, co-ordination, and performance. New Haven: Yale University Press. 
Scholte, J. A. (2005). Global trade and finance. In John Baylis, \& Steve Smith (Eds.), The Globalisation of World Politics: an introduction to international relations (3rd ed. pp. 599-620). Oxford: Oxford University Press.

Schwarz, F. J. (1998). Advice and consent: The politics of consultation in Japan. Cambridge: Cambridge University Press.

Sugimoto, Y. (1997). An Introduction to Japanese society. Cambridge: Cambridge University Press.

Sztompka, P. (1993). The sociology of social change. Oxford: Blackwell Publisher Oxford.

Takuro, S. (1989). A Radical Interpretation of Postwar Economic Policies. In Tessa Morris-Suzuki, \& Seiyama Takuro (Eds.), Japanese Capitalism since 1945: critical perspective (pp. 28-73). Armonk: M.E. Sharpe.

Wilks, S., \& Wright, M. (1991). The Japanese Bureaucracy in the Industrial Policy Process. In Stephen Wilks, \& Maurice Wright (Eds.), The Promotion and regulation of industry in Japan (pp. 32-50). London: McMillan.

Yasuhiro, N. (1998). Politicians, Bureaucrats, and Policymaking in Japan. In Frank Gibney (Ed.), Unlocking the bureaucrat's kingdom: deregulation and the Japanese economy (pp. 41-52). Washington DC: Brookings Institution.

\section{Notes}

Note 1. One of the most prominent pollution issues was the 'Minamata Bay Case', leading to the dead of about one thousand people and several thousand suffered from mercury poisoning. Water contamination (so-called itai-itai disease, a case of cadmium poisoning), urban air pollutions representing other critical pollution issues in the late 1960 s, early 1970 s.

Note 2. The allegations were, that despite the Ministry of Health and Welfare was aware of the contamination, the Ministry, by not acting according to public interest, helped to protect the enormous profits made by the pharmaceutical industries.

Note 3. When foreign rescue crews arrived with specially trained dogs to search the rubble for survivors, they were told that their dogs were not permitted to go to the devastated areas as according to regulations dogs would need to be quarantined for one month.

Note 4. There have been two exceptions. In 1976 and 1979, the LDP lost its majority in both houses of the parliament. The LDP quickly cooperated with several successful independent and conservative candidates, to reach a working majority, thus restoring its control.

Note 5. In the aftermath of the Lockheed Scandal in 1976, as a small group defected from the LDP, to form the New Liberal Club (NLC). Even as the NLC gained significant public support, but won only few seats in the Diet, the LDP and NLC formed on December 26, 1983, the first coalition since 1947. Eventually, after the failure in the 1986 elections, the NLC was dissolved and its six lower house members rejoined the LDP in 1986. 